\title{
aniki
}

Revista Portuguesa da Imagem em Movimento Portuguese Journal of the Moving Image

\section{Sob o signo do provisório: um diretor entre três cidades} Daniela Giovana Siqueira ${ }^{1}$

\author{
O cineasta brasileiro Maurício Gomes Leite ${ }^{2}$ institui no seu primeiro \\ filme enquanto diretor e roteirista, A Vida Provisória (1968) ${ }^{3}$, o des- \\ locamento como ato fundador da narrativa e o provisório como signo
}

${ }^{1}$ Universidade de São Paulo, Escola de Comunicações e Artes, ECA, 05508-020,
São Paulo, Brasil. Pesquisadora financiada pela FAPESP - Fundação de Amparo à
pesquisa do Estado de São Paulo.
${ }^{2}$ João Maurício Amarantes Gomes Leite (1936-1993). Crítico, jornalista e cineasta. Nascido em Montes Claros, Minas Gerais, transferiu-se para a capital Belo Horizonte para trabalhar como jornalista. Enquanto crítico, escreveu para a conceituada Revista de Cinema, que na década de 1950 foi considerada por Paulo Emílio Sales Gomes como a principal publicação de crítica cinematográfica do Brasil. Leitor contumaz dos Cahiers du Cinéma, foi um dos primeiros brasileiros a escrever sobre Jean-Luc Godard, e seus textos influenciaram a geração cineclubista belo-horizontina da década de 1960 reunida no cineclube do Centro de Estudos Cinematográficos de Minas Gerais (CEC). Jair Tader da Fonseca informa que "no mesmo período, escreveu crítica de cinema para os jornais Estado de Minas e Diário da Tarde, entre outros órgãos de imprensa; na década de 1960, no Rio de Janeiro, trabalhou no Correio da Manhã e no Jornal do Brasil, além de ter colaborado com outros periódicos. Como cineasta, dirigiu e produziu o documentário de média-metragem $O$ Velho e o Novo (1966), sobre o crítico literário Otto Maria Carpeaux no contexto político-cultural brasileiro, e o longa-metragem de ficção $A$ Vida Provisória (1968); escreveu o texto da locução de Cinema Novo (1967), documentário de Joaquim Pedro de Andrade; produziu o documentário Tostão - A Fera de Ouro (1970), de Ricardo Gomes Leite. Em meados da década de 1970, Maurício Gomes Leite mudou-se para Paris, onde trabalhou na Unesco até seu falecimento" (2014, 164). Permanecem inéditos trabalhos que se dediquem ao estudo da sua obra crítica e cinematográfica.

${ }^{3}$ A Vida Provisória é uma obra rara ainda não registrada em trabalhos dedicados à historiografia do cinema brasileiro, nem estando acessível em retrospectivas temáticas em mostras ou festivais de cinema. Realizado no Rio de Janeiro produzido pelas companhias Tekla Filmes, Saga Filmes, Luiz Carlos Barreto Produções Cinematográficas, J. P. de Carvalho Produção e Administração Cinematográfica Ltda., contou com empréstimos bancários de pelo menos quatro instituições, entre elas o Banco Nacional de Minas Gerais. Recebeu os prêmios à melhor atriz coadjuvante para Joana Fomm, no $4^{\circ}$ Festival de Brasília em 1968, e ao melhor argumento para Maurício Gomes Leite, no Prêmio Governador do Estado de São Paulo em 1969. Na base de dados Filmografia Brasileira, administrada pela Cinemateca Brasileira, disponível no site www.cinemateca.gov.br, a ficha do filme inclui a informação de que teria sido selecionado para representar o Brasil no Festival de Locarno de 1969. Mais dados sobre a obra estão sendo levantados no âmbito da pesquisa de doutorado "Perdidos e Malditos: política, produção cinematográfica e memória," desenvolvida pela autora no Programa de Pós-Graduação em Meios e Processos Audiovisuais (ECA/USP), com bolsa de financiamento da Fundação de Amparo à Pesquisa do Estado de São Paulo (FAPESP). O filme pode ser encontrado em cópia combinada em película, bitola $35 \mathrm{~mm}$, no acervo da Cinemateca do Museu de Arte Moderna do Rio de Janeiro (MAM-RJ). 
da vida política brasileira no final da década de 1960. Gomes Leite afirmou que este trabalho "é uma crítica filmada ou um documento sobre as obsessões políticas, estéticas e particulares de seu autor" (Leite 1975, s.p.). Sob nossa perspectiva, A Vida Provisória é uma obra em que três capitais brasileiras -Rio de Janeiro, Belo Horizonte e Brasília - influenciam o olhar do diretor, moldando, de diferentes formas, a presença física e psicológica do protagonista nos espaços enquadrados pela câmera. Este artigo, portanto, está dedicado à análise deste filme, e busca compreender a dimensão do espaço no interior de sua construção fílmica, entendendo como o cinema potencializa a discussão entre a cidade real e os discursos feitos sobre as cidades.

Para construir um parâmetro de análise para as suas imagens, a partir da relação cinema e cidade, alinhamos esforços com autoras que buscam ampliar o entendimento sobre pressupostos tradicionalmente apresentados em relação ao âmbito espacial, como a geógrafa inglesa Doreen Massey:

Muitas e muitas vezes o espaço é conceituado (ou supõe-se que seja) simplesmente como o oposto negativo do tempo. (...) tempo e espaço têm de ser pensados conjuntamente: que isso não é um mero floreio retórico, mas que influencia o que pensamos sobre ambos os termos, que pensar tempo e espaço conjuntamente não significa que eles sejam idênticos (por exemplo, em alguma quarta dimensionalidade indiferenciada); pelo contrário, significa que a imaginação de um terá repercussões (nem sempre inteiramente seguidas) para a imaginação do outro e que espaço e tempo estão implicados um no outro, que isto revela alguns problemas que, até então, pareciam (logicamente, intratavelmente) insolúveis, e que isso tem consequências para o pensamento sobre a política e o espacial. $(2008,40)$

Pensar o filme A Vida Provisória como uma narrativa em deslocamento por diferentes paisagens permite potencializar o estudo da memória de forma a conectar as esferas de tempo e de espaço como integrantes comuns ao ato de lembrar. Neste sentido, Giuliana Bruno aponta a seguinte ideia:

As cidades são, por excelência, espaços que não apenas evocam as memórias, mas as constroem e as contêm. O mesmo ocorre em relação à memória virtual que construímos através das telas, historicamente a cinematográfica, hoje também a da televisão, do computador e do celular. (Bruno apud Broggi 2005, 23-24)

As paisagens percorridas pela personagem principal de A Vida Provisória não serão aqui pensadas como elemento estático que se ocupa apenas em se fazer cenário para o protagonismo do tempo que passa. Estas paisagens, pelo contrário, são espaços moldados politicamente pela designação de cidades, formas intensamente dinâmicas, justapostas e simultâneas, que a mobilidade cinematográfica tem a capacidade de transpassar, gerando novas imagens resultantes dos ângulos, lentes, movimentos de câmera e montagem. A linguagem 
fílmica permite reenquadrar as cidades, possibilitando a criação de novos sentidos visuais para o espectador, que passa "a viajar através de múltiplos espaços e tempos” (Mello 2011, 146). Esta capacidade do cinema de propor uma nova moldura emocional ao espectador referenda a proposição de uma mudança de paradigma sobre a fruição fílmica proposta por Bruno:

Preso por um olhar lacaniano, cujo impacto espacial permaneceu inexplorado, o espectador do cinema foi transformado em um voyeur. Em contraste, quando falamos de site-seeing, nós sugerimos que, devido à mobilização espaço-corpórea do cinema, o espectador é na realidade um voyageur, um passageiro que atravessa um palpável terreno emotivo. (2007, 15-16)

Cecília Mello, por sua vez, explica desta forma a achega anterior de Bruno:

O que me parece mais importante e relevante nessa cruzada contra o modelo ótico é a ênfase proposta por Giuliana Bruno no cinema como uma arte espacial, e na mobilização emocional proporcionada pelo potencial espacial da própria linguagem cinematográfica. Partindo desse deslocamento teórico de sight (visão) para site (local), de voyeur para voyageur, Bruno (2007) recupera, entre outros, alguns estudos de Sergei Eisenstein ([1938] 2010) para aproximar o cinema da arquitetura, duas artes análogas por serem práticas do espaço. (2011, 147)

Neste artigo, ao invés de lançar um olhar compartimentado para as instâncias de tempo e espaço, a proposta é imbricar essas duas perspectivas por meio da metodologia da análise fílmica, dedicando atenção à construção do espaço fílmico no encontro da câmera com o espaço urbano concreto. Filiamos nossa proposta de análise fílmica a trabalhos como os de Jean-Claude Bernardet (1985), Claudio Almeida (1999) e Eduardo Morettin (2013), "identificando como as características de imagem e som se põem como respostas a demandas que vêm da esfera do político e do social" (Xavier 2007, 15).

\section{Rio de Janeiro}

O protagonista de A Vida Provisória, Estêvão (Paulo José), é um jornalista que trabalha na cidade do Rio de Janeiro. Com acesso a importantes políticos brasileiros, ele recebe das mãos de um Ministro de Estado a missão de transportar documentos secretos, capazes de denunciar atos ilícitos que estão sendo feitos contra interesses do povo brasileiro, em pleno regime ditatorial militar. Para cumprir com esse objetivo, a personagem se desloca a pé, de carro ou de avião por três cidades brasileiras - Rio de Janeiro, Belo Horizonte e Brasília, como já foi mencionado -, três espaços políticos e sociais que são apresentados pelo discurso fílmico com diferentes sentidos semânticos. 
O filme inicia-se com uma tomada aérea em que a câmera sobrevoa uma longa extensão de prédios, sem conferir ao espaço urbano uma identidade própria. A cena poderia ter sido gravada em qualquer grande cidade brasileira. Justaposta a essa imagem, uma trilha sonora instrumental, salpicada por elementos percussivos, instaura uma atmosfera de urgência que remete ao suspense. Essa sequência, constituída sobre um espaço densamente edificado, serve de base para a apresentação dos créditos iniciais. Quando a câmera chega ao chão, após apresentar a primeira metade dos créditos, uma mulher aparece andando pela cidade, de lenço na cabeça e enormes óculos escuros. Ela olha para todos os lados. A câmera mira os prédios da rua por onde ela caminha e destaca o aglomerado de paredes unidas umas às outras. Um grande paredão de concreto é testemunha de seu percurso até que ela entra no apartamento de Estêvão. Seu nome é Paola (Dina Sfat), e ela é amante do protagonista.

Mais à frente na narrativa, o espectador é informado de que as cenas se passam no Rio de Janeiro. Ao apresentar a cidade cercada pelo concreto, deixando ausentes das imagens as famosas praias e da trilha sonora o som mundialmente conhecido da Bossa Nova, o filme estabelece com a cidade uma relação muito diferente da que foi maciçamente construída no imaginário social nacional e internacional, colocando o espectador em confronto com o discurso convencional construído sobre a "Cidade Maravilhosa." Em A Vida Provisória, as imagens sucessivas dos prédios e o som instrumental da trilha sonora, estabelecem a sensação de opressão e deixam claro o olhar que o diretor lança sobre o espaço carioca.

Dentro do apartamento, Estêvão fala com preocupação sobre "essa coisa toda lá fora," referência indireta ao clima político brasileiro de então, que passava por uma ditadura militar. Paola informa que o marido, diplomata, foi transferido para outro país e que ela deve partir com ele ainda naquela tarde. Todas as cenas feitas no interior do apartamento transbordam o limite da discussão entre público e privado, abordagem individual e coletiva do tecido político brasileiro daquele momento, sintetizada no filme pelo casal de classe média. O envolvimento político de Estêvão em manifestos abertos aponta, na visão de Paola, a possibilidade de terem a relação descoberta. A divergência política deles também é notória. Paola representa a direita conservadora e reacionária, que se volta única e exclusivamente para si. Estêvão é a esquerda libertária e revolucionária, que quer pensar o Brasil como um todo. 


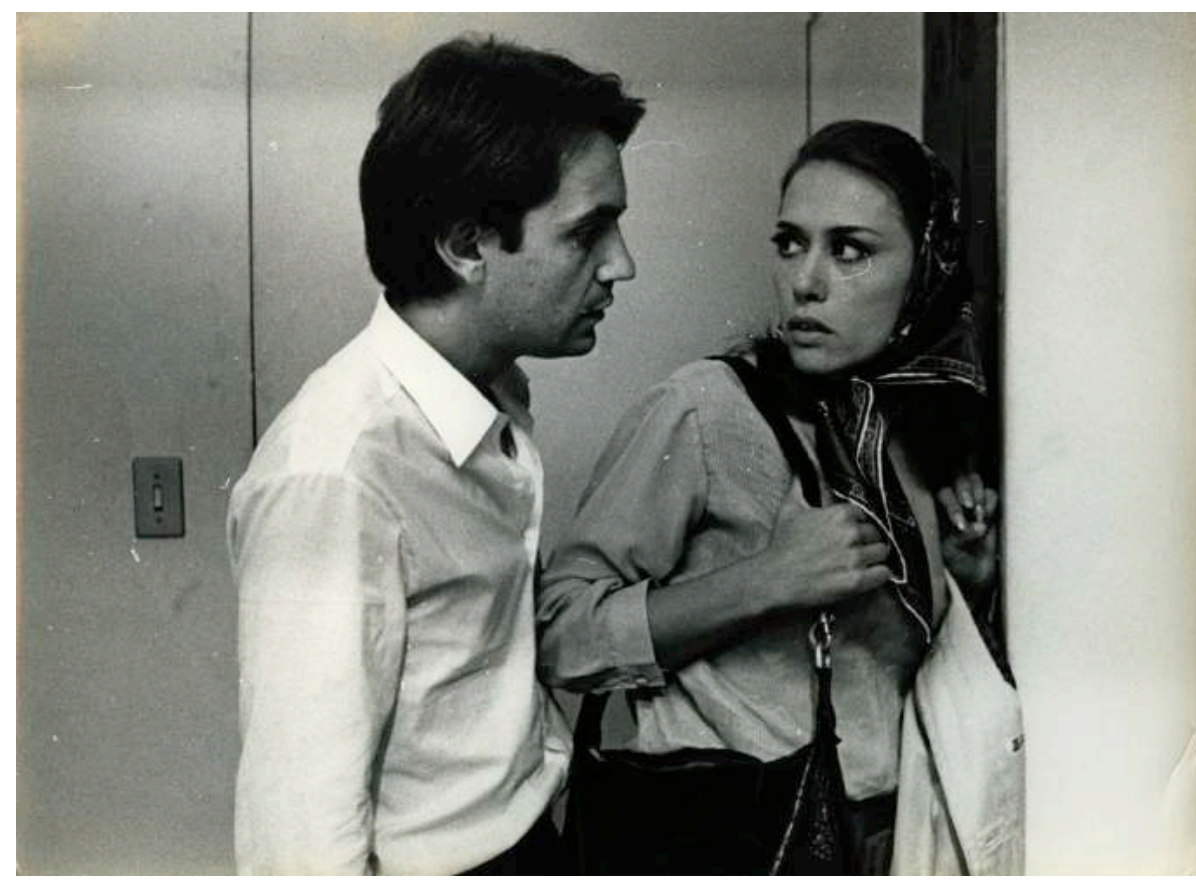

Imagem 1: O casal Estevão e Paola na cidade do Rio de Janeiro. A Vida Provisória (Maurício Gomes Leite, 1968)| (C) Cinemateca Brasileira

Em um longo diálogo que se dá na sala do apartamento, Estêvão expõe seu ponto de vista sobre a beleza do povo e as contradições brasileiras. A personagem aparece enquadrada entre duas fotos. Ao seu lado direito, o registro do lindo rosto de Paola. Ao seu lado esquerdo, com arma em punho, uma fotografia still de Paulo Martins (Jardel Filho), jornalista e poeta, personagem do emblemático filme de Glauber Rocha Terra em Transe (1967). Nesse momento, assim como o Paulo de Glauber, Estêvão nos informa ser o intelectual poeta diante do destino trágico da política nacional. ${ }^{4}$

Os encontros marcados por longos diálogos entre Estêvão e Paola se dão unicamente no interior do apartamento. Há em jogo um amor proibido e, por isso, precisa ser escondido, mas o interessante no filme é que o diretor estende essa atmosfera fechada da vida privada do casal para o retrato que faz da cidade do Rio de Janeiro como um todo. O clima vivido no espaço privado contamina a atmosfera pública. Com essa operação, o diretor borra o imaginário social sobre a cidade carioca que sempre se apresenta nos produtos midiáticos nacionais, sobretudo nas novelas, como o lugar da diversão e da alegria, de uma população com mentalidade mais aberta e menos puritana em comparação com o restante do país.

\footnotetext{
${ }^{4} \mathrm{O}$ tema da crise do intelectual frente à postura a ser tomada diante dos rumos políticos do país, já estava instaurado no cinema brasileiro no precursor $O$ Desafio - produzido em 1964 e lançado em 1966 -, dirigido por Paulo César Saraceni e em filmes como Terra em Transe (1967), de Glauber Rocha e O Bravo Guerreiro, obra lançada em 1969 e produzida simultaneamente à A Vida Provisória, em 1968.
} 
No Rio, os deslocamentos de Estêvão são sempre feitos de táxi. De um prédio a outro, recebendo incumbências e colhendo informações, o tempo pede urgência e as distâncias devem ser percorridas rapidamente. Estêvão entra no carro e no plano seguinte chega ao destino. Nesses deslocamentos não se vê a paisagem. Com essa construção, o filme reforça a premissa de que o espaço não deve ser visto como uma representação estática, pois este, como o tempo, também se presta, igualmente, à compreensão da mobilidade (Bruno 2007). Essa sensação de deslocamento instantâneo de Estêvão pela cidade nos chama a atenção para o pensamento de Bruno e contribui, na análise, para a percepção de um Rio de Janeiro que se apresenta como centro político e não apenas destino de férias.

O movimento da personagem pelo espaço, sintetizado aqui pelo deslocamento feito de carro é outra escolha do diretor que amplifica a sensação de opressão da cidade do Rio de Janeiro opressão que se expressa pelo enquadramento de uma cidade cinza e edificada. Sob o ponto de vista temporal, não é Estêvão quem controla e distribui o tempo que gasta com sua vida, mas as contingências profissionais e sócio-históricas do país naquele momento. Assim, no Rio de Janeiro, Estêvão não pode se dar ao luxo da flânerie e, portanto, não há fruição da paisagem. O deslocamento mecanizado, tendo o carro como meio de transporte colocado a serviço da urgência, desloca a personagem da premissa de ocupante da pólis para transformá-la em alguém que atravessa o espaço. Esse movimento se materializa pelo ato de deslocamento marcado por um tempo de partida e de chegada. A análise do tempo e do espaço na narrativa pode, assim, ser pensada sob um ponto de vista imbricado: urgência cronológica que molda e é moldada pela opressão espacial, instâncias coconstitutivas de Estêvão naquele momento. O cinema pensado como uma arte espacial torna-se, portanto, um lugar privilegiado para a promoção de uma discussão sobre tempo e espaço, seguindo as ideias de Massey:

O que poderia significar reorientar essa imaginação, questionar esse hábito de pensar o espaço como uma superfície? Se, em vez disso, concebêssemos um encontro de histórias, o que aconteceria às nossas imaginações implícitas de tempo e espaço? (...) A temporalidade foi louvada como a dimensão vital da vida, da própria existência. $\mathrm{O}$ argumento aqui é que o espaço é igualmente vivo e igualmente desafiador, e que, longe de ser morto e fixo, a própria enormidade de seus desafios significa que as estratégias para dominá-lo têm sido muitas, variadas e persistentes. (2008, 23-35)

Pela composição fílmica, a rápida passagem do tempo é formalmente acompanhada da sensação de diminuição das distâncias percorridas no espaço através do uso do carro. Ao chegar a seu destino, e estando dentro do prédio, todas as vezes que Estêvão olha para a paisagem a tela mostra ao espectador um mar de edificações. Ele está irremediavelmente sufocado, e essa construção espacial da paisagem também reverbera sobre o corpo da personagem. 
Quem é, portanto, Estêvão? Um jornalista influente de classe média, originário da cidade de Belo Horizonte, que vai para o Rio de Janeiro trabalhar. Nesta cidade, quando está em contato com a esfera pública, sua expressão corporal sempre exibe a sensação de incerteza e insegurança. Seu rosto estampa uma preocupação exacerbada, os olhos seguem todo o tempo bastante abertos. Estêvão nos apresenta um corpo inquieto, uma mente confusa reagindo à opressão construída pelo filme sobre o espaço. O mar carioca não é apresentado e o alívio para ele parece distante. O corpo da personagem é um importante aspecto a ter em conta na análise, pois reage de forma diferente em cada cidade percorrida na narrativa, e isso colabora para reforçar nossa premissa que procura pensar o espaço e não somente o tempo no interior da construção fílmica.

\section{Belo Horizonte}

Estevão viaja do Rio de Janeiro para Belo Horizonte. A praia carioca é mostrada pela primeira vez através da janela do avião, em um curto sobrevoo. No plano seguinte, o avião passa a sobrevoar o bairro da Pampulha, em Belo Horizonte, local em que está localizado o aeroporto da cidade, paisagem símbolo do impulso arquitetônico modernizante da capital mineira. Nesse bairro, a pedido do prefeito Juscelino Kubitscheck ${ }^{5}$, o arquiteto Oscar Niemeyer projetou o maior complexo modernista do Brasil no início da década de 1940: o Conjunto Arquitetônico da Pampulha, composto por um cassino, uma casa de baile, uma igreja e um Iate Club. Era a primeira vez que o Brasil edificava em sua arquitetura o traçado moderno preconizado pelo arquiteto Charles-Édouard Jeanneret-Gris, mais conhecido pelo pseudônimo de Le Corbusier. Mas no filme o que vemos é uma construção de imagens que decididamente inverte o sentido moderno do espaço sobrevoado pelo avião: em uma sequência primorosa, construída sob a voz over do narrador, o diretor mostra, na primeira cena, imagens aéreas do bairro da Pampulha, e, na cena seguinte, uma série de fotografias, imagens fixas da cidade - ruas, cinemas de rua, carros, fachadas de restaurantes, pessoas dentro deles sentadas em mesas, colegiais andando com os cabelos ao vento à frente de um tradicional instituto de ensino público. São imagens estáticas que se referem ao cotidiano comum e substituem o movimento nas cenas. Cobrindo sonoramente essa imobilidade, ouve-se em uma das frases: "Difícil

\footnotetext{
${ }^{5}$ Juscelino Kubitschek de Oliveira (1902-1976), conhecido como JK, nasceu no Estado de Minas Gerais e foi uma personalidade política brasileira com gestões marcadas por impulsos modernizantes e desenvolvimentistas. Entre 1940 e 1945 foi prefeito da cidade de Belo Horizonte, onde mandou construir o Conjunto Arquitetônico da Pampulha. Já entre 1956 e 1961 foi presidente da república e inaugurou uma nova capital federal, Brasília, em abril de 1960. O filme A Vida Provisória percorre essas duas cidades, filmando espaços frutos de decisões políticas de JK, e conferindo-lhes leituras diferentes das que foram construídas pelos registros históricos oficiais.
} 
era compreender por que uma cidade, feita para um poema selvagem, ainda continuava, hoje, imóvel, como um retrato de família”. Ao escolher parar o fluxo do movimento com a introdução de imagens fixas, a construção fílmica desta sequência sobrepõe ao espaço de Belo Horizonte uma discussão sobre os tempos presente, passado e futuro da cidade. Com isso, o filme marca para o espectador, por meio da própria linguagem, o seu ponto de vista sobre a cidade que começa a apresentar na tela.

Discutindo a vacância temporal e o descompasso moderno de Belo Horizonte, A Vida Provisória constrói um julgamento corrosivo sobre a velocidade do movimento da cidade: uma cidade congelada, como se estivesse presa a algo inexplicável. A própria narração não consegue explicar a quê. À morte? As imagens estão fixas, mesmo quando retratam pessoas em movimento. Uma grande stasis fundamenta esta apresentação da capital mineira. Imagem e som formam uma radiografia do lento compasso atribuído por vários cinéfilos e críticos de cinema à cidade de Belo Horizonte, com destaque para as dificuldades de ali se fazer cinema. ${ }^{6}$ Neste trecho, o filme faz um elaborado comentário a duas especificidades culturais amplamente ligadas ao imaginário social projetado nacionalmente sobre os mineiros: o conservadorismo e o tradicionalismo (Santiago 2014).

A sequência da chegada de Estêvão a Belo Horizonte denuncia aproximações biográficas entre o diretor Maurício Gomes Leite e a personagem. Maurício nasceu na cidade de Montes Claros, norte do estado de Minas Gerais e na capital, Belo Horizonte, construiu sólida carreira no jornalismo, com destaque para a crítica de cinema. Mas foi quando morou na cidade do Rio de Janeiro que Gomes Leite reuniu condições necessárias para enfrentar o exercício da realização de um filme, pois na década de 1960, Belo Horizonte não oferecia as bases para o desenvolvimento de produções fílmicas de longametragem. Este dilema mineiro para a produção de filmes foi registrado pelo próprio Maurício Gomes Leite, quando já morava no Rio de Janeiro, em sua coluna de crítica cinematográfica no Jornal do Brasil, escrita em abril de 1966:

Em abril do ano passado, terminaram as filmagens de $A$ Hora e Vez de Augusto Matraga e O Padre e a Moça, voltando para Belo Horizonte os estagiários das duas equipes, pertencentes ao CEC [Centro de Estudos Cinematográficos] e à Escola de Cinema, com um entusiasmo pela realização cinematográfica que contagiou a todos os que aqui tinham ficado fazendo cineclubismo ou crítica. Alguns faziam planos de ir para o Rio, como caminho mais rápido para conseguir entrar nos esquemas de produção de filmes e chegar, afinal, ao que todos pretendiam, dirigir. (apud Ribeiro 1997, 79)

\footnotetext{
${ }^{6}$ Aspecto verificado em entrevista com o cineasta mineiro Geraldo Veloso, diretor de Perdidos e Malditos (1970), dada à autora para a pesquisa "Perdidos e Malditos: política, produção audiovisual e memória fora do eixo."
} 
Em A Vida Provisória, Estêvão também é um jornalista que quer fazer um filme, como explica o narrador em uma das primeiras cenas. Esta voz informa que foram encontrados na cidade de Brasília recortes e anotações de um filme autobiográfico que Estêvão pretendia fazer "depois que tudo passasse." A narração prossegue, dizendo que as notas deixadas são incompletas, e algumas escritas de forma vaga. Explica também que amigos se reuniram e levaram por diante a empreitada de realizar a história que o espectador irá assistir. Esta sequência instaura uma mimese entre personagem principal e diretor: homens, jornalistas migrados de outra cidade, com desejo de produzir um filme. Em nossa análise, esta mimese, exposta pela própria obra, exacerba a tese de que, em A Vida Provisória, Maurício Gomes Leite nos apresenta uma escrita de si.

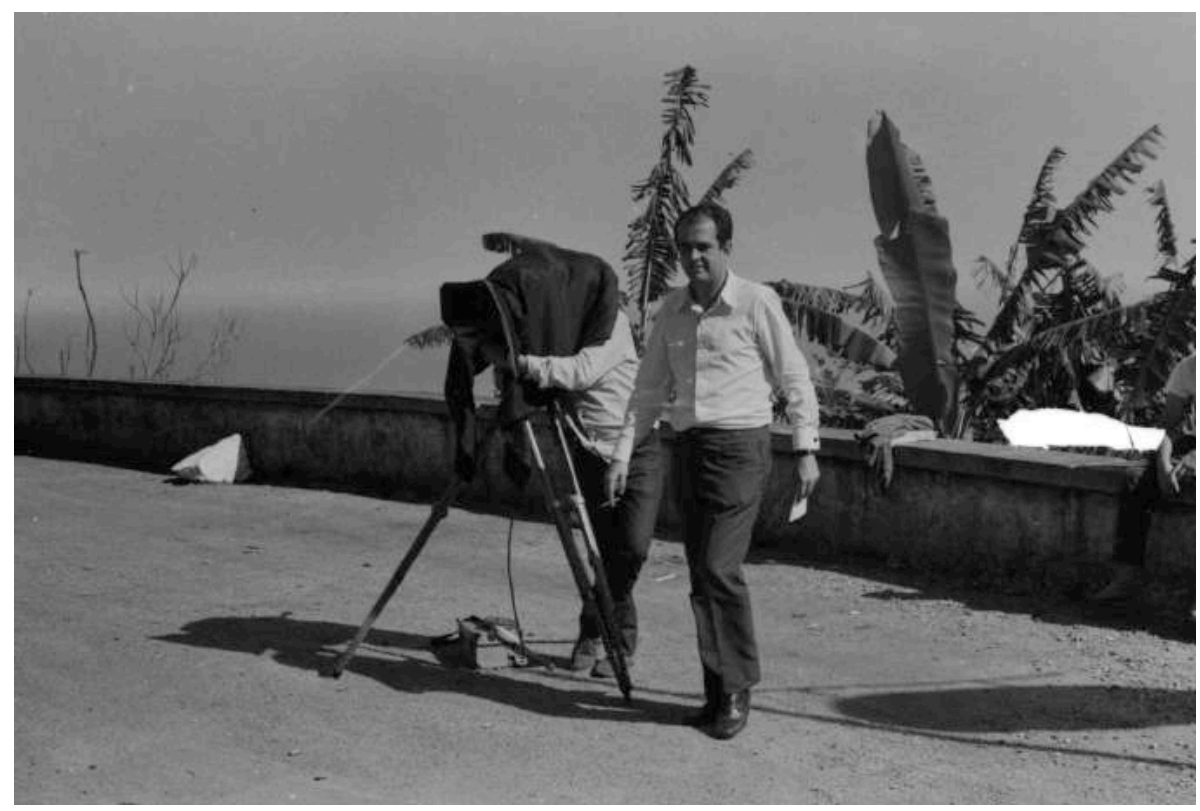

Imagem 2: O diretor Maurício Gomes Leite durante as filmagens de A Vida Provisória (1968) | (c) Cinemateca Brasileira

A configuração de Estêvão na narrativa destaca o próprio eu do diretor, refletido nas escolhas profissionais da personagem e no percurso adotado por ele no filme: de Belo Horizonte, Maurício vai viver no Rio de Janeiro e depois em Brasília, antes de partir para a França, onde vem a falecer. Acreditamos que o filme também desenrola escolhas espaciais e memorialísticas do próprio diretor. Assim, quando o narrador apresenta, na sequência da chegada de Estêvão, uma reflexão sobre o espaço e o tempo belo-horizontinos, podemos concluir que se trata de uma crítica íntima, que parte do diretor/roteirista, e que contribui para o reforço do imaginário estereotipado, reverberado nacionalmente, de que os mineiros são uma gente fechada, que ocupa um espaço que se transforma muito lentamente ao longo do tempo. 
No filme, as diferentes percepções do diretor sobre cada cidade apresentada na narrativa tornam-se cada vez mais claras. Nesta análise, destacamos o deslocamento como elemento que materializa a ideia de movimento. A forma como Estêvão se desloca em Belo Horizonte - o tempo todo a pé, mesmo para chegar aos compromissos de trabalho - apresenta também uma guinada na maneira como o diretor observa o novo espaço a ser mostrado. A câmera que acompanha Estêvão se aproxima do solo e produz enquadramentos que destacam o desenho montanhoso da geografia, em contraposição à planície carioca. A cidade é cercada por um grande paredão montanhoso e as ruas quase sempre são ladeiras íngremes, despovoadas, onde os carros se contam com os dedos de uma só mão. Os deslocamentos são acompanhados por música clássica. O corpo de Estêvão parece menos tenso, ele caminha e observa tudo, o que chama a atenção do espectador, pois na narrativa ele agora é emissário do Ministro do Subsolo e transporta documentos importantíssimos, precisando obter junto de um antigo amigo da cidade importantes informações sigilosas. Ou seja, não há mudança na situação de urgência na vida de Estêvão, mas o novo espaço parece agir de forma diferente sobre a personagem, influenciando o seu "estado de espírito."

Mesmo em meio à urgência trazida na alma desde o Rio de Janeiro, Estêvão encontra tempo para procurar uma antiga namorada, Lívia, e ir ao cinema com ela. O caminhar dos dois por lojas e ruas enquanto conversam cria no espectador a sensação de que as horas correm em velocidade mais lenta. Os locais da cidade parecem próximos e seus habitantes se conhecem, pois, estando com Lívia, Estêvão é reconhecido pelo irmão mais novo de um antigo amigo de Faculdade. $\mathrm{O}$ caminhar pela cidade e a facilidade de encontrar pessoas conhecidas são dois pontos muito comuns no discurso que a própria população de Belo Horizonte faz sobre seus costumes.

Outra sequência que enfatiza a diferença proposta pelo filme entre Rio de Janeiro e Belo Horizonte é o momento em que Estêvão e Lívia estão se despedindo. A noite cai e os sinos da igreja da Boa Viagem (matriz da capital) anunciam as seis horas da tarde. O plano seguinte mostra um carro de som que anuncia que Estêvão, "jornalista subversivo e mau" está na cidade. Lívia diz: “- Estêvão, já é tarde. Tenho que ir. A cidade toda vai ficar sabendo." Os sinos da igreja e um carro de som são símbolos que, no Brasil, são reconhecidamente ligados ao universo de cidades interioranas. No filme, Belo Horizonte - então a terceira maior capital do país - é tratada, definitivamente, como uma cidade pequena. Para Paola, no Rio de Janeiro o anonimato é possível. Para Lívia, em Belo Horizonte, jamais.

A lembrança da relação amorosa vivida por Lívia e Estêvão na juventude é marcada no filme por uma bela sequência que situa em diversas paisagens da cidade o cotidiano vivido pelos dois, antes que Estêvão escolhesse ir morar no Rio de Janeiro. Maurício Gomes Leite leva estas cenas para vários espaços públicos de Belo Horizonte, al- 
ternando locações internas e externas. Na sala de aula de uma escola, uma fórmula de matemática aparece escrita no quadro. Estêvão diz: "Lívia foi para mim uma fórmula de matemática que eu não sabia na prova de fim de ano." Embaixo do vão do colégio, "o jornal do colégio”. Na praça, ela veste uniforme colegial, ele já está com roupas de universitário: "o namoro na praça." De volta ao vão do colégio, agora é a vez de Lívia rememorar: "Estêvão foi para mim o autor português que eu não conhecia na prova de fim de ano." A cena se abre para uma rua ampla, cercada por muitas árvores, onde se vê apenas um carro em movimento e, à frente dele, duas crianças fazendo ziguezague em uma bicicleta: "a bicicleta que descia a ladeira, pela manhã." Depois, Lívia e Estêvão atrás de uma árvore, se beijando: "o primeiro bater do sexo." Surge a foto de uma criança. Ouve-se Estêvão: "Lívia foi para mim o sofá na sala quando os pais dormiam. E uma foto da infância." Finalizando a sequência, em uma estação de trem, Lívia está vestida com o uniforme de uma colegial. Cabelos compridos, saia rodada azul, blusa branca, meias $7 / 8$ e sapato tipo boneca. O trem chega e a ouvimos em voz over: "Estêvão foi para mim o retorno na estação e a despedida sem retorno.” Ao fundo, pouco a pouco uma música clássica é substituída pelo som do trem que se afasta.

A construção fílmica desta sequência não é feita por meio do tradicional flashback, mas privilegia a exposição de uma memória espacial por meio de uma montagem alternada que, no trecho descrito acima, remonta ao passado das personagens, garantindo uma simultaneidade temporal e destacando a descontinuidade espacial ao mostrar cenas de diversos lugares da cidade onde os jovens se encontravam. Nessa construção fílmica, a memória está toda impregnada pelo espaço da cidade. O diretor escolhe compor a memória de uma forma poética, levando o espectador para as paisagens que foram testemunha daquele tempo passado, vivido pelo casal. Para Giuliana Bruno, as cidades são como "camadas de sedimentos, a soma de tudo aquilo que seus habitantes carregam dentro de si. (...) É, sobretudo, através do espaço e não do tempo que se movem as memórias" (apud Mello 2013, 130).

A cena da bicicleta é especialmente bonita, pois a câmera acompanha o ziguezague feito por ela e o espectador pode sentir a demora, a ausência de qualquer pressão que marcou a história de amor do casal no passado. O som reitera essa apropriação bucólica do tempo e do espaço, pois é composto por uma trilha sonora instrumental tocada ao piano. Há um tempo referenciado e percorrido, claro. Mas o espaço torna-se o elemento que abrigou e agora reapresenta aos espectadores aquelas vivências. "A memória é, portanto, um ponto de conexão entre o evento lembrado, a pessoa que o lembra e o espaço da lembrança" (Mello 2013, 130).

A cidade de Belo Horizonte torna-se uma protagonista não ficcional que acolhe nessa parte do filme o melhor da memória da personagem principal. Se referendarmos a proposição de que Estêvão 
é uma mimese do diretor, reiteramos a ideia de amor e ódio à cidade, muito frequentemente colocada pela geração de cineastas mineiros das décadas de 1960 e 1970, que afirmava ser preciso deixar Belo Horizonte para viver a liberdade e conseguir trabalhar. Mas, ainda assim, é essa cidade que permanece sendo o lugar que representa a poesia no filme.

\section{Brasília}

Estêvão sai de Belo Horizonte rumo a Brasília, cidade onde se passa o terço final do filme. O ritmo retorna para o compasso da urgência: a missão recebida no Rio de Janeiro precisa ser cumprida. Os deslocamentos voltam a ser feitos por meio de carro, mas agora, diferentemente do Rio de Janeiro, em uma cidade marcada por um planejamento modernizante, pautado por longas vias planas que traçam a assimetria urbanística da capital brasileira, edificada pelo presidente Juscelino Kubitscheck no planalto central. A cidade foi planejada e agrupada por setores - o de lojas, o habitacional, a esplanada dos ministérios (centro administrativo do Governo Federal) o que torna os deslocamentos mais longos de um ponto a outro. No Brasil é comum o comentário de que em Brasília, até para comprar pão na padaria, é preciso usar carro, veículo obrigatório; uma ideia que tem aprofundado Paula Monteiro:

Os meios de locomoção parecem criar certo tipo de espacialidade na qual as relações se desenvolvem em sentido inverso ao contato físico. Dá-se uma desterritorialização do processo social no qual a comunicação liga de maneira simultânea espaços paralelos separados entre si $(2008,195)$.

Na primeira cena, Brasília é mostrada de dentro de um carro em movimento que percorre o Eixo Monumental: vemos os prédios dos ministérios erguidos, tendo entre eles vastas áreas abertas, completamente desocupadas. ${ }^{7}$ No som, ouvimos a voz do narrador dizer "quando Brasília foi inaugurada, todas as rádios diziam: falamos do coração do Brasil." O filme começa a assumir um contorno documental, trazendo para a narrativa uma discussão sobre o Brasil no ano de 1968. A trilha sonora, composta até então por música clássica instrumental, inclui os primeiros acordes de "Ponteio," uma composição de Edu Lobo e Capinam, vencedora do III Festival da Música Popular Brasileira em 1967. ${ }^{8}$ Brasília é o único espaço percorrido pelo filme

\footnotetext{
7 O Eixo Monumental é uma avenida que se localiza no centro do Plano Piloto de Brasília. Estende-se por dezesseis quilômetros, fazendo a ligação entre os sentidos leste e oeste da capital do Brasil. Ao longo de sua extensão estão localizados diversos monumentos e prédios administrativos do poder executivo federal, entre eles a esplanada dos ministérios.

${ }^{8}$ Entre os anos de 1965 e 1972, a história da Música Popular Brasileira foi marcada pela presença em festivais da canção realizados por grandes emissoras de televisão, como a TV Excelsior, a TV Globo e a TV Record. Esses eventos cumpriram a função de revelar intérpretes, compositores e instrumentistas ao grande público,
} 
que recebe a companhia de uma canção (letra e música), trazendo para o espectador uma segunda camada de linguagem. Por sua vez, porque "Ponteio" obedece aos moldes de uma canção de protesto, reflete um desejo de intervenção política do artista na realidade social do país. O ritmo sincopado do arranjo, baseado em um instrumento tradicional, o violão, se molda com perfeição à letra de conteúdo político (Severiano 2008).

Na capital da república, a personagem de Estêvão vai perdendo pouco a pouco sua dimensão privada de homem idealista e saudoso de suas origens, que sente a perda de seu grande amor Paola, para assumir-se como condutor das principais discussões políticas em pauta no Brasil. A questão agora é coletiva. O filme está na capital do Brasil e discute pobreza, repressão política, ditadura militar. Estêvão conduz todos esses temas, pois são seus deslocamentos que proporcionam a captação da situação política vivida naquela cidade. Brasília será uma presença esmagadora sobre ele, impondo fim à sua trajetória de deslocamento. Lá, Estêvão será morto.

O carro volta a ser o veículo que o transporta, mas, diferentemente do que acontecia no Rio de Janeiro, a personagem é mostrada dentro do carro, e essa escolha da câmera mostra para o espectador que as distâncias percorridas são maiores. Com isso, é possível observar um pouco mais a paisagem brasiliense, onde se vê uma planície deserta, a vegetação raquítica do cerrado, muita poeira, uma grande antena de transmissão televisiva no horizonte, e alguns caminhões com caçamba que trabalham em obras da cidade.

transformando-se também em um importante palco político para a época, como explica Carlos Basualdo: "No período que começa com o início da ditadura militar em 1964 - e que em certa medida se encerraria em 1968, ao ser decretado o AI-5 , a música popular havia se tornado o veículo privilegiado de dissensão política. No imaginário cultural da época, correspondia à música popular, em grande parte, o papel de articular um ideal de nação - concebido em função de revalorizar suas "raízes" culturais - e de exercer a liberdade de expressão em clara oposição ao projeto ideológico e político dos militares. Para um importante setor da música popular, fortemente influenciada pela ideologia associada aos Centros Populares de Cultura (CPC), tratava-se de veicular uma mensagem claramente contestatória, e inclusive de conotações revolucionárias, enquanto ao nível formal a intenção consistia em manter-se supostamente fiel à tradição musical popular, ou seja, a de articular o projeto de uma identidade nacional que o pensamento de esquerda mais ortodoxo encontrava em germe nas expressões populares." $(2007,12)$ Edu Lobo se filiava ao grupo ligado à vertente "nacional-popular," que enfatizava o violão como instrumento central, junto com nomes como Chico Buarque, Milton Nascimento, Geraldo Vandré e Gozaguinha. Em contraponto, propondo interpretar e reformular a informação sobre o entendimento de popular, artistas como Caetano Veloso, Gilberto Gil e Tom Zé enfrentaram o público e os jurados dos festivais ao introduzirem a guitarra elétrica em suas canções, propondo uma mistura com o rock e o pop internacional. Em 1967, a final do III Festival da Música Popular Brasileira, promovido pela TV Record, deixou clara a forte presença dessas duas vertentes estético-políticas no cenário cultural brasileiro, expressando um resultado equilibrado entre as duas correntes: em primeiro lugar ficou "Ponteio" (Edu Lobo/Capinam); em segundo, "Domingo no Parque" (Gilberto Gil); em terceiro, "Roda Viva" (Chico Buarque); e, em quarto, "Alegria, Alegria” (Caetano Veloso). 
O carro chega a uma cidade satélite. Andando, Estêvão procura por uma pessoa de nome Cavalcanti em meio a um aglomerado de casas construídas com materiais precários, como papelão e madeirite, habitadas pelos migrantes. Encontra a pobreza acumulada em torno da cidade ainda em construção, inaugurada oito anos antes. Essa sequência denuncia um problema social criado pela fundação da nova capital. Os migrantes, em sua maioria pessoas do norte e nordeste do Brasil, foram os trabalhadores que ergueram a nova sede do governo federal. O planejamento urbanístico os expulsou do centro da cidade, legando a eles as chamadas cidades satélites, espaços mal organizados no entorno da capital, mas fora do contorno do Distrito Federal, com pouca ou nenhuma estrutura de abastecimento e escoamento de águas, energia elétrica, asfalto, hospitais, escolas e habitação. Vários trabalhadores se transformaram em migrantes definitivos, por não conseguirem dinheiro para voltar para suas cidades de origem. Muitos chefes de família morreram nas obras, deixando mulher e filhos legados à própria sorte. ${ }^{9}$

Enquanto busca por Cavalcanti, Estêvão conversa com moradores e bebe cerveja em um bar, onde pergunta para uma garçonete que disse conhecer Cavalcanti: "Você mora aqui?" Ela responde: "Eu vivo aqui. Vim de Paracatu." ${ }^{10}$ A fala da personagem, que diz que vive ao invés de afirmar que mora, unida à imagem de seu corpo que demonstra certa desolação, remete para uma leitura de transitoriedade vivida por um momento compulsório. Seu corpo magro e jovem se apresenta cabisbaixo e curvado diante de seu interlocutor. No final do diálogo com a moça, registra Estêvão: "Mas você não sabe aonde ele está?" Ela: "Não. Parece que morreu, ou se mudou. Tanto faz."

O deslocamento de Estêvão de volta para Brasília é feito sem ser mostrado. No percurso, já no plano piloto, a câmera de desloca livremente pelo espaço, registrando na paisagem um muro pichado com a frase: "Ditadura mata estudante": trata-se de uma cena totalmente documental. O narrador afirma que Brasília vivia uma situação excepcional, de formações confusas. Na trilha, o som da canção "Ponteio" volta mais alto, em trecho com verso engajado: "Parado no meio do mundo, senti chegar meu momento / Olhei pro meio do mundo, e nem via, nem sol, nem sombra, nem vento / Quem me dera agora eu tivesse a viola prá cantar / Quem me dera agora eu tivesse a viola prá cantar." Nas imagens, sobre ruas sem asfalto cobertas por muita poeira ao redor do Eixo Monumental, migrantes mestiços andam em grupo. Do outro lado, homens e mulheres jovens, estudantes e bran-

\footnotetext{
${ }^{9}$ No documentário Conterrâneos velhos de guerra (1990), o diretor Vladimir Carvalho aborda os pontos mais dramáticos da construção de Brasília, a partir do ponto de vista dos operários que foram levados para cidades satélites na periferia e não puderam viver na cidade que ajudaram a construir. Esses trabalhadores ficaram conhecidos pelo nome de 'candangos.'

${ }^{10}$ Paracatu é uma cidade do noroeste de Minas Gerais, localizada próxima a Brasília e distante pouco mais de $300 \mathrm{~km}$ de Montes Claros, cidade natal do diretor do filme.
} 
cos seguram faixas de protesto com frases como "Fim," "Luz," "Stop," "Um, dois, três, quatro," "Basta e fora." A sequência se fecha com outra tomada claramente documental, captada provavelmente de forma improvisada, pois o enquadramento é precário e faz ver escoteiros caminhando em fila, passando à frente de dois policiais militares em pé no meio de uma rua.

Durante 26 segundos, mais uma vez de dentro de um carro que se desloca em linha reta, a câmera registra em travelling, enquadrando em um grande plano aberto, a esplanada dos ministérios. Pela primeira vez, Brasília nos é mostrada como uma cidade adensada, com muitos carros estacionados em torno dos prédios. A capital da república foi construída sobre um extenso planalto, o que permite a onipresença do sol no terreno, pois não há obstáculos naturais para encobri-lo. Porém, a intervenção do homem na paisagem, marcada pela presença dos edifícios, é, na cena, a responsável pela ausência da luz. O intervalo entre as construções coloca o sol ora de frente para a câmera, ora encoberto pelos grandes prédios, intermitência que estabelece na cena um instigante jogo entre claro e escuro, naturalmente proporcionado pela luz do sol na paisagem.

No início da noite, um grande plano geral abarca a maior parcela possível de uma Brasília vista do interior de um carro em movimento. Estêvão fala em voz off: "Desfalece o comércio de atacados. Vão descansar os pedreiros, os funcionários, os engenheiros. Mas permanecem acordados os garçons, os músicos, os motoristas de táxi. Mil outras profissões noturnas. A cidade muda de mão. Num golpe." Na última frase, a câmera está fixa e mostra alguns prédios em plano aberto. O enquadramento se abre ainda mais em um zoom out muito veloz, que distancia a imagem dos prédios, reforçando para o espectador a noite que cai sobre a cidade. Nessa altura, a trajetória pessoal de Estêvão já se confunde com a condução política autoritária vivida pela nação. A noite que cai sobre a cidade anuncia a entrada de Estêvão na escuridão. O filme assume uma forma ensaística ao longo de sua narrativa, e não tem medo de se mostrar histórico, ao se abrir para a discussão sócio-política brasileira.

Estêvão é capturado por dois agentes não identificados, que o espancam e o colocam em um carro. Dessa vez não se vê imagens a partir de dentro do carro em movimento. O deslocamento nessa sequência é montado por três cenas captadas por uma câmera fixa. $\mathrm{Na}$ primeira se vê o carro partindo; a segunda mostra Brasília vista de cima à noite; a última cena mostra o carro estacionando para pegar os documentos que Estêvão havia guardado no aeroporto. Ao não colocar a câmera dentro do carro para mostrar as personagens em deslocamento, preferindo substituir o trajeto por uma imagem fixa da cidade (segunda cena), o diretor reafirma, usando apenas um plano, o uso da noite como metáfora da escuridão democrática do período histórico. É importante que esse recurso de linguagem seja feito sob o céu de Brasília, centro político nacional. 
O destino final é um apartamento. Lá se encontra uma mulher jogada em um sofá que, tal como Estêvão, está bastante machucada. Descobrimos que se trata da mesma garçonete - que transparecia em seu corpo a transitoriedade de um momento compulsório - com quem Estêvão havia conversado na cidade satélite. Seu nome é Márcia (Márcia Rodrigues), uma militante que se fazia passar por migrante para se esconder da repressão, o que explica o fato de ela conhecer Cavalcanti, o homem desaparecido que deveria receber das mãos de Estêvão os documentos enviados do Rio de Janeiro pelo Ministro do Subsolo. O reencontro dos dois amplifica a denúncia feita pela narrativa sobre a tortura como mecanismo amplamente utilizado pelo regime ditatorial durante os 20 anos em que os militares permaneceram no poder no Brasil.

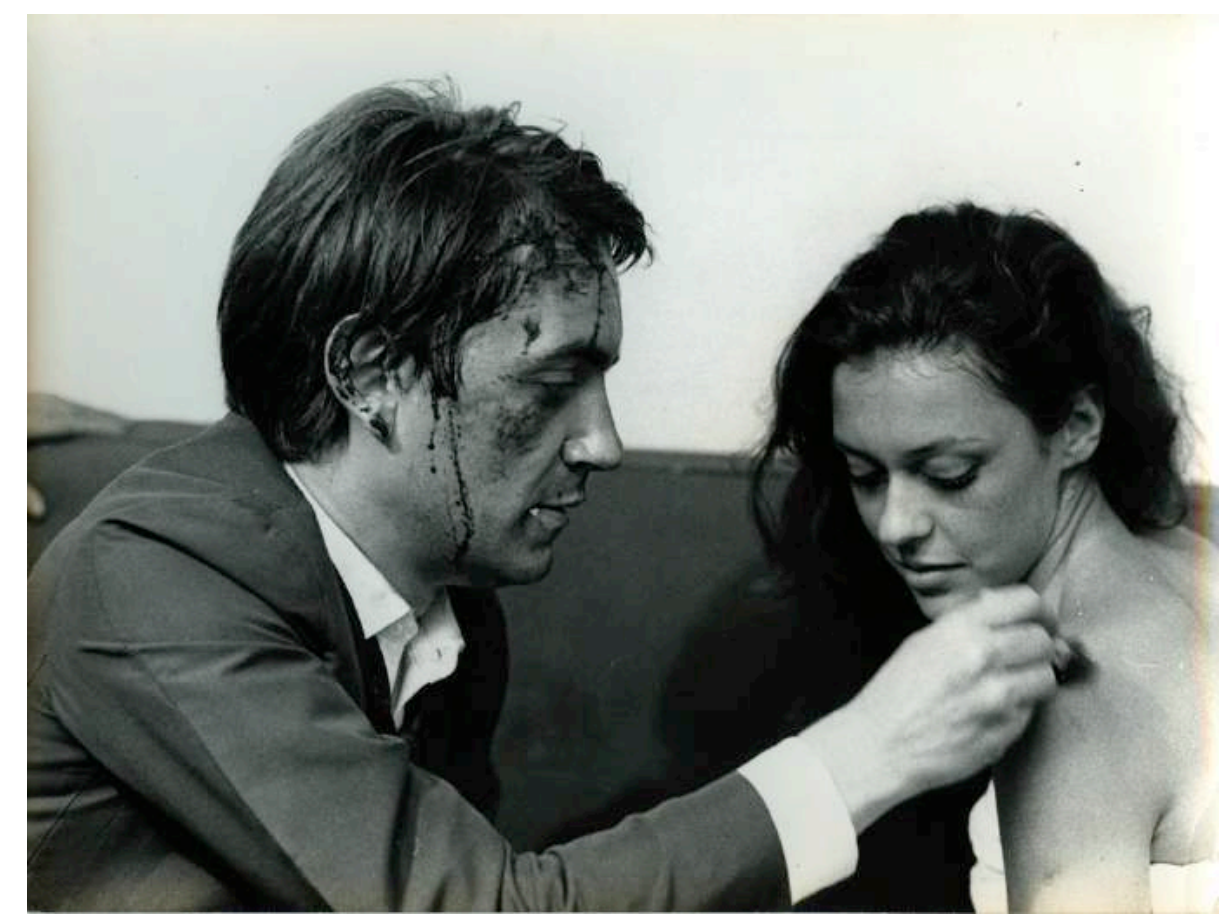

Imagem 3: Estevão, Márcia e a tortura física imposta pelo regime ditatorial brasileiro. A Vida Provisória (Maurício Gomes Leite, 1968) | @ Cinemateca Brasileira

A paisagem sonora construída para as cenas no apartamento, em que os agentes da repressão se fazem presentes, é composta pelo silenciar das vozes das personagens. Não há diálogos, nem mesmo gritos. A mediação sonora é feita pelo narrador, que descreve o que se passa em cena e, quando necessário, substitui a fala das personagens, ditando para o espectador o som que deveria sair de suas bocas, que, nas imagens, estão em movimento. O espaço é mal iluminado por uma lâmpada presa por um fio no teto. Ela balança de um lado para outro e deixa uma sensação ainda mais fantasmagórica no espaço privado. Os corpos combalidos estão marcados por suor e sangue, mas o olhar de Márcia, nítido pelos enquadramentos que a câmera faz sobre a personagem, traz a marca de uma esperança na vitória de 
seus ideais. Ouvimos do narrador: "Márcia diz que não tem importância, porque chegará a aurora." A sequência do enclausuramento no espaço apertado e sombrio dura 7 minutos e 12 segundos no tempo fílmico que, somados ao lento compasso das ações desenvolvidas, resulta na sensação de corresponder à passagem de toda uma noite.

Do apartamento, Estêvão é levado pela manhã para um enorme descampado relativamente próximo ao Eixo Monumental, como em seguida a câmera, em uma tomada aérea, revelará. Lá, ele recebe mais chutes e socos, e termina por testemunhar a queima dos documentos que transportava. A câmera enquadra esse espaço em um grande plano aberto, e o que se vê é a capital da república erma, sem uma densidade conformada e ainda em construção, num tempo em que o país teve sua autonomia política desconstruída. Estêvão se levanta e a câmera mostra em um plano aéreo que o espancamento se deu em um lugar não muito distante da praça dos Três Poderes, núcleo dos poderes Executivo, Legislativo e Judiciário brasileiros. Uma terra sob um regime ditatorial, sem lei ou proteção aos cidadãos.

Na última cena do filme, a câmera mostra um descampado em um plano fixo, e faz um movimento panorâmico da direita para esquerda, para enquadrar Estêvão. Um homem se aproxima por trás e mata o jornalista com uma arma de fogo. A câmera acompanha o corpo de Estêvão e mostra que a execução se deu exatamente em frente ao Palácio do Planalto, sede do executivo federal onde se encontra o Gabinete Presidencial. A morte de Estêvão nesse local, em um filme onde os espaços registados não se apresentam de forma aleatória, remete também para uma das mortes da democracia brasileira, registrada pela História na década de 1960.

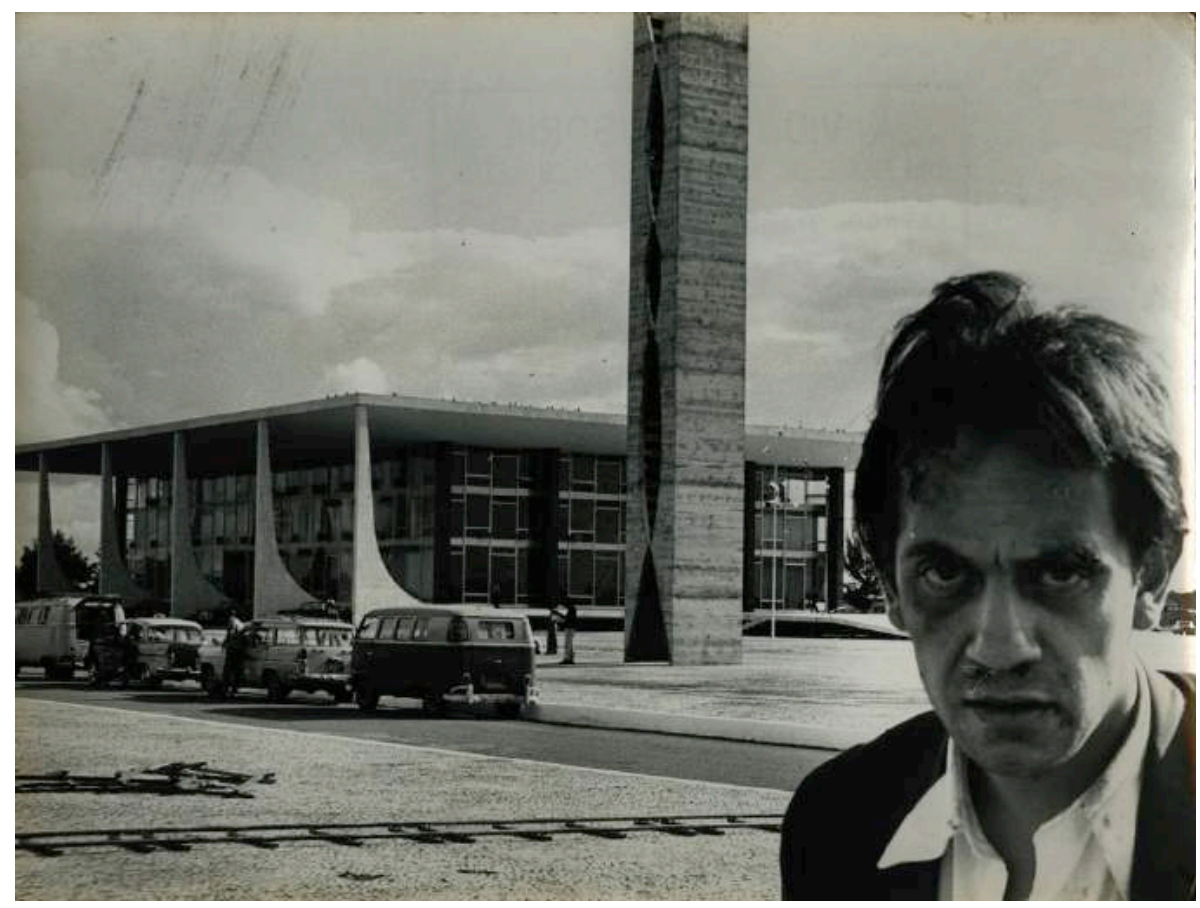

Imagem 4: Estevão no centro do poder político brasileiro em Brasília. A Vida Provisória (Maurício Gomes Leite, 1968) | (c Cinemateca Brasileira 


\section{Sob o signo do provisório}

As relações amorosas, pessoais e de trabalho de Estêvão vão se deslocando pelos espaços das cidades do Rio de Janeiro, Belo Horizonte e Brasília sob o signo do provisório, estabelecendo em paralelo uma cartografia emocional com a trajetória do próprio diretor e roteirista do filme, Maurício Gomes Leite. A narrativa de A Vida Provisória está muito centrada na história de vida do próprio diretor e, portanto, calçada em uma observação biográfica sobre os espaços percorridos pela câmera naquele ano de 1968. O também jornalista Maurício Gomes Leite viveu nas três cidades retratadas, e, segundo sua própria afirmação citada na introdução desse artigo, o filme é o resultado de suas obsessões políticas, estéticas e particulares.

O tempo e o espaço podem ser capturados quando o ato de olhar as paisagens é retirado do contato face a face com o cotidiano e transportado para o registro mecanizado do cinema. Esse momento, depois de gravado, permanecerá inalterado. Fora da engrenagem do cinema, o tempo continua em frente, e, junto com ele, a paisagem segue recebendo novos contornos e significados frutos dessa passagem. O tempo é dinâmico, a paisagem e os espaços também são. Por isso, nas palavras de Doreen Massey:

Reconhecemos o espaço como estando sempre em construção. Precisamente porque o espaço, nesta interpretação, é um produto de relações-entre, relações que estão, necessariamente, embutidas em práticas materiais que devem ser efetivadas, ele está sempre no processo de fazer-se. Jamais está acabado, nunca está fechado. Talvez pudéssemos imaginar o espaço como uma simultaneidade de estórias-até-agora. $(2008,29)$

Acreditamos, portanto, que seja salutar, em trabalhos que utilizam filmes como objeto central de pesquisa, pensar conjuntamente as relações entre tempo e espaço, sem que isso reduza os dois a uma identidade única. Assim promovemos uma perspectiva de soma destes vetores no momento da análise: "Pensar sobre história e temporalidade tem, necessariamente," continua Massey, "implicações (quer as reconheçamos ou não) em relação ao modo como imaginamos o espacial" $(2008,40)$.

O filme A Vida Provisória apresenta, a partir de nossa análise, uma discussão calçada soberanamente sobre o espaço para também pensar o tempo: um espaço que apresenta e discute o movimento e se mostra protagonista na narrativa, quando estruturado pelo diretor na chave do deslocamento. Assim, a cidade do Rio de Janeiro é opressora; Belo Horizonte, estática; Brasília, injusta e contraditória. Todos esses espaços estão em um tempo histórico, pois discutem os fatos políticos que se desenrolaram sob o calor dos acontecimentos reais do período. 


\section{BIBLIOGRAFIA}

Almeida, Claudio A. 1999. O cinema como "agitador de almas": "Argila', uma cena do Estado Novo. São Paulo: Annablume.

Basualdo, Carlos. 2007. "Vanguarda, cultura popular e indústria cultural no Brasil”. In Tropicália: uma revolução na cultura brasileira [1967-1972], Carlos Basualdo (org.). São Paulo: Cosac Naify.

Bernardet, Jean-Claude. 1985. Cineastas e imagens do povo. São Paulo: Editora Brasiliense.

Broggi, L. 2005. "Atlas of Emotion: Intervista a Giuliana Bruno”. Aria $1,14-29$.

Bruno, Giuliana. 2007. Atlas of Emotion: Journey in Art, Architecture and Film. Nova York: Verso.

Fonseca, Jair Tadeu da. 2014. "A crítica de autor e sua vida provisória. Maurício Gomes Leite e a crítica cinematográfica e literária de seu tempo". In Coleções literárias, organizado por Patrícia Peterle, Andrea Santurbano e Maria Aparecida Barbosa, 163-175. Rio de Janeiro: 7Letras.

Leite, Maurício Gomes. 1975. "A vida provisória ou a crítica filmada". Jornal de Brasília (Agosto): s.p.

Massey, Doreen. 2008. Pelo Espaço. Rio de Janeiro: Bertrand Brasil.

Mello, Cecília. 2011. "An-danças Urbanas em Xiao Wu e Na Cidade de Sylvia”. Revista Eco-Pós (UFRJ, Rio de Janeiro) vol.14 (outubro). Disponível em http://revistas.ufrj.br/index.php/eco_pos/article/viewFile/9 $16 / 856$.

——_. 2013. "Um conto de duas cidades". In Cinema, Globalização e Transculturalidade, org. por Alessandra S. Brandão, Anelise Corseuil e Ramayana Lira, 119-138. Blumenau: Nova Letra.

Monteiro, Paula. 2008. "Passagens na Metrópole Paulistana do Século XXI”. Novos Estudos Cebrap 82 (novembro): 191-199.

Morettin, Eduardo. 2013. Humberto Mauro, cinema, história. São Paulo: Alameda.

Ribeiro, José Américo. 1997. O Cinema em Belo Horizonte: do cineclubismo à produção cinematográfica na década de 60. Belo Horizonte: Editora UFMG.

Santiago, Silviano. 2014. Mil rosas roubadas. São Paulo: Companhia das Letras.

Severiano, Jairo. 2008. Uma história da música popular brasileira. São Paulo: Ed.34. 
Xavier, Ismail. 2007. Sertão Mar: Glauber Rocha e a estética da fome. São Paulo: Cosac Naif.

\section{FILMOGRAFIA}

A Vida Provisória. [longa-metragem] Dir. Maurício Gomes Leite. Tekla Filmes/Saga Filmes/Luiz Carlos Barreto Produções Cinematográficas et al., Brasil, 1968. 100mins.

Recebido em 30-06-2016. Aceite para publicação em 27-10-2016. 